Belén Chaar, F., Fernández, J.P., Sepúlveda, L.R., \&

Rubilar, T. (2021). The influence of density on survival and larval development in the sea urchin Arbacia dufresnii (Echinodermata: Echinoidea). Revista de Biología Tropical, 69(S1), 334-345. DOI 10.15517/rbt.v69iSuppl.1.46365

DOI 10.15517/rbt.v69iSuppl.1.46365

\title{
The influence of density on survival and larval development in the sea urchin Arbacia dufresnii (Echinodermata: Echinoidea)
}

\author{
Florencia Belén Chaar ${ }^{1,2,3}$ \\ Jimena Pía Fernández $z^{2,3}$ \\ Lucas R. Sepúlveda ${ }^{2,3}$ \\ Tamara Rubilar ${ }^{2,3 *}$
}

1. National University of Patagonia San Juan Bosco, Bv. Almte. Brown 3051, Puerto Madryn, 9120, Chubut, Argentina; chaar@gmail.com

2. Laboratory of Chemistry of Marine Organisms. Instituto Patagónico del Mar. Faculty of Natural Sciences and Health Sciences. National University of Patagonia San Juan Bosco. Puerto Madryn headquarters. Argentina; jpfernandez@cenpat-conicet.gob.ar; 1sepulveda@cenpat-conicet.gob.ar, rubilar@cenpat-conicet.gob.ar (*Correspondence).

3. Biological Oceanography Laboratory- Centro para el Estudio de Sistemas Marinos- Centro Nacional Patagónico, Centro Científico Tecnológico del Consejo Nacional de Investigaciones Científicas y Técnicas- Consejo Nacional de Investigaciones Científicas y Técnicas de Argentina, Bv. Almte. Brown 2915, Puerto Madryn, 9120, Chubut, Argentina.

Received 13-VII-2020. Corrected 03-VIII-2020. Accepted 18-IX-2020.

\begin{abstract}
Introduction: Density is one of the critical factors in echinoderm larvae for aquaculture purposes. Echinoplutei larvae are very sensitive to overcrowding. High culture density can lead to problems with bacteria or protozoa, decreasing survival and generating abnormal morphotypes. Objective: To evaluate the effect of culture density on survival and larval growth in the sea urchin Arbacia dufresnii. Methods: Two days after fertilization of $A$. dufresnii we we kept treatments at 1, 3, 5 and 10 larvae. $\mathrm{ml}^{-1}$, with three replicates each. We recorded survival and abnormal morphotypes periodically, as well as growth:somatic rod length, total length, and length of the post oral arms,. we applied generalized linear models. Results: Survival is dependent on density, time and replicates, and their interactions. Larval growth depended on density and time, also with interaction between the variables. The treatment of 5 larvae. $\mathrm{ml}^{-1}$ had the highest survival and larval condition. Conclusions: Larval culture of A. dufresnii had the best results at 5 larvae. $\mathrm{ml}^{-1}$.
\end{abstract}

Key words: Echinoplutei, growth, morphometry, aquaculture, treatments.

Echinoderm embryos, particularly sea urchins and starfish, have been studied for more than 170 years (Rubilar \& Crespi-Abril, 2017). The culture is simple and has been used as a classical animal model for embryological studies (Williams \& Anderson, 1975). More recently, echinoderm embryos have been used for ecotoxicology analysis (Rahman, Tsuchiya, \& Uechara, 2009) and molecular studies (McClay, 2011; Hinman \& Burke, 2018). Additionally, the development of simple protocols facilitates the aquaculture of the entire life cycle of sea urchins. This progress has been crucial in the further development of aquaculture and in 
the implementation of repopulation projects in areas affected by overexploitation, or by mass mortality, as found in Japan, Chile and China, among other areas (Unuma, Sakai, Agatsuma, \& Kayaba, 2015; Brady \& Scheibling, 2006). As a result, advances in this area are of major interest for research, conservation and aquaculture purposes.

The echinoderm larvae culture is crucial to any conservation or aquaculture project. There is a need of having certain, optimal growing conditions in order to obtain good results in the successful production of post settled juveniles. Variables, such as temperature, salinity (Astudillo, Rosas, Velásquez, Cabrera, \& Maneiro, 2005; Domínguez, Rosas, Velásquez, Cabrera, \& Mata, 2007), feeding, and larval culture density (Astudillo et al., 2005; Buitrago $\&$ Lodeiros-Seijo, 2005) are among the most important factors.

There exists a wide variety of values in the optimal culture density depending on the species, with values ranging from 0.025 to 3 larvae. $\mathrm{ml}^{-1}$ (Buitrago \& Lodeiros-Seijo, 2005; Salas-Garza, Carpizo-Ituarte, Parés-Sierra, Martínez-López, \& Quintana-Rodríguez, 2005; Kalam-Azad, Mckinley, \& Pearce, 2010; Díaz-Pérez \& Carpizo-Ituarte, 2011). High culture densities can affect the quality of the water, increasing the risk of contamination due to the increase in organic matter, as well as the increase in waste metabolic substances (Lamare \& Barker, 1999; Salas-Garza et al., 2005; Domínguez et al., 2007; Clark, Lamare, \& Baker, 2009; Kalam-Azad et al., 2010). High densities can also generate stress or competition for space or food, affecting the normal development of the organisms (Pechenik, 1999; García et al., 2005) Inadequate density cultures usually translate into decreased survival, changes in the growth of organisms, and/or a higher incidence of abnormal phenotypes, such as the absence of arms or very small bodies with very long arms (Clark et al., 2009; Kalam-Azad et al., 2010). However, considering the natural mortality during the larval stage and the specific culture conditions, it is necessary that the initial quantity of organisms is sufficient to be able to obtain a production of juveniles justifying the required investment and efforts (Stotz, 2014). For aquaculture purposes, the maximum viable density of a species is of particular importance. In addition, when analyzing a culture, it is important to consider the morphometrics of the larvae, both in terms of size and as well as in terms of the proportion of its structures as these can provide information on the culture conditions and the effects on development. To estimate larval growth, both PO (post oral arms) and TL (total length) of sea urchin larvae have been two of the most frequently used indicators in recent years. The PO is one of the most frequently used measures as it is, generally, very sensitive to changes in environmental variables (Fenaux, Strathmann, \& Strathmann, 1994; Hart \& Strathmann, 1994; Eckert, 1998; Jimmy, Kelly, \& Beaumont, 2003; Cárcamo, Candia, \& Chaparro, 2005; Domínguez et al., 2007; Clark et al., 2009; Rosas, Velásquez, Fernández, Mata, \& Cabrera, 2009; Adams, Sewell, Angerer, \& Angerer, 2011; Fernández, 2019). At the same time, measuring the length of the somatic rod (SO), can be an important indicator of growth parameters related to ambient factors (Clark et al., 2009; Feunax et al., 1994).

The sea urchin Arbacia dufresnii is abundant along the Argentinian and Chilean coasts, inhabiting coastal areas from Río de la Plata $\left(35^{\circ} \mathrm{S}\right)$ in the Southwest Atlantic to Puerto Montt $\left(42^{\circ} \mathrm{S}\right)$ in the South Pacific, including the Malvinas Islands (Bernasconi, 1966). This species has been the subject of several scientific studies. Specific ecological aspects have been described, such as their abundance, distribution, role in the ecosystem and diet in different environments (Vásquez, Castilla, \& Santelices, 1984; Larraín, Mutschke, Riveros, \& Solar, 1999; Penchaszadeh \& Lawrence, 1999; Zaixso \& Lizarralde, 2000; Teso, Bigatti, Casas, Piriz, \& Penchaszadeh, 2009; Newcombe, Cárdenas, \& Geange, 2012; Brogger et al., 2013; Castro, 2014; Epherra, 2016; Epherra, Martelli, Morsan, \& Rubilar, 2017). Descriptions of certain physiological aspects of adult individuals have been described, such as the reproductive cycle 
and gonadal composition (Brogger \& Ivanov, 2010; Epherra et al., 2015a; Epherra et al.,2015b; Parra et al., 2015; Zárate, Díaz de Vivar, Ávaro, Epherra, \& Sewell, 2016). Additionally, specific aspects of the early stages of the life cycle of this species have also been described, such as fertilization under controlled conditions (Fernández, Epherra, Sepúlveda, \& Rubilar, 2019), complete embryonic development and specific stages of larval development (Bernasconi, 1942; Brogger, 2005; Fernández, 2019). Furthermore, there have been descriptions of the response of the larvae to ocean acidification (Catarino, De Ridder, Gonzalez, Gallardo, \& Dubois, 2012) and the monitoring of development in natural conditions (Kino, 2010). These studies have served as a basis for the exploration of the aquaculture potential of the species (Rubilar et al., 2016). However, there are, still, few studies which have succeeded in determining the optimal larval culture density under laboratory conditions. Neither are there any large number of studies defining and clarifying the possible consequences of culturing in a variety of densities. The aim of this study is to evaluate the influence of culture density on survival and on the larval development of the sea urchin $A$. dufresnii which is a new species within aquaculture.

\section{MATERIALS AND METHODS}

Spawning and fecundity: The adult specimens of $A$. dufresnii, belonging to the broodstock of the experimental aquarium of the Centro Nacional Patagónico, Consejo Nacional de Investigaciones Científicas y Técnicas de Argentina (CONICET), were the subject of investigation. For the induction of spawning, four females and three males of $A$. dufresnii were injected with $0.3 \mathrm{ml}$ of $0.5 \mathrm{M} \mathrm{KCl}$ solution (Strathmann, 1987). The female gametes were collected individually on an aqueous medium and, were, then, mixed in a single container and quantified in triplicate. Male gametes were dry harvested in a single container and kept on ice until used to preserve their viability (Ettensohn, Wessel, \& Wray,
2004; Strathmann, 2014; Ettensohn, 2017). A total of 800000 eggs were placed in a liter of sea water filtered up to $1 \mu \mathrm{m}$ and sterilized with UV light. Fertilization was carried out by using a 1:100000 v/v dilution of sperm according to Fernández et al. (2019). After $30 \mathrm{~min}$, the percentage of fertilization success was verified and calculated under a light microscope (Leica DM 2500) on the basis of observing the fertilization membrane in the eggs.

Embryo culture: The fertilized eggs were kept for $48 \mathrm{~h}$ with constant and gentle aeration, at a temperature of approximately $17^{\circ} \mathrm{C}$ and at a salinity of 34-35 ppm. At $24 \mathrm{~h}$ after fertilization, the culture volume was tripled in order to decrease the density of developing organisms. After $72 \mathrm{~h}$, the larvae in the prism stage were transferred to a new container, quantified, and the corresponding dilutions were undertaken for each treatment.

Larvae culture: Four treatments with varying densities of larval culture, were produced. The treatments involved included:1 larva. $\mathrm{ml}^{-1}, 3$ larvae. $\mathrm{ml}^{-1}, 5$ larvae. $\mathrm{ml}^{-1}$, and 10 larvae. $\mathrm{ml}^{-1}$. All of the treatments were executed in triplicate and the larvae were kept in sealed systems consisting of 1 liter glass containers. The larvae were cultured for 14 days, which corresponds to 2 to 14 days postfertilization (DPF) of development. This took place under controlled conditions and similar water quality. The larvae were fed, daily, with a mix of microalgae Tetraselmis suecica and Isochrysis galbana, at an initial rate of 10000 , and this was gradually increased every two days to reach 40000 cells.larvae $^{-1}$ (Unuma et al., 2015). Sea water changes took place every $48 \mathrm{~h}$, removing $50 \%$ of the total volume of each container, using filters with a $50 \mu \mathrm{m}$ mesh to avoid the loss of larvae, and adding acclimatized sea water (water at the same temperature as that of the crops to be replaced). With each water exchange, $\mathrm{pH}$, temperature, salinity and nitrogen compounds were measured in each specific replica. The final water exchange was based on applying commercial 
tests for nitrates (Nutrafin), nitrites (Nutrafin) and ammonia (Tetra).

Survival: Five counts were undertaken during the experiment (that is, every 3 days). Using a zoom microscope (Stemi 2000, Carl Zeiss) and using a bogorov chamber, the number of larvae observed in a $30 \mathrm{ml}$ aliquot for each treatment and replicates was quantified. Only organisms with normal morphology and vitality were taken into account on the basis of the descriptions of Fernández et al. (2019). The ability to swim, the emergence of typical structures during larval development, homogeneity of the development of each treatment and the left-right symmetry in individuals, was clearly observed. The survival percentage was calculated at: Survival $=$ (number of larvae at a given point in time $\mathrm{t}+1$ ) / (initial larval number at a given point in time $\mathrm{t}) * 100$.

Growth: In order to study larval growth over time, photographs of between three to five larvae were taken of each replica, every three days. For this purpose, a Leica DM 2500 bright field microscope and imaging software for microscopy were used. Then, using the ImageJ software, the length of the somatic rod (SO) (length from the apical end to the beginning of the post oral arm), the length of the post oral arm (PO) (length from the end of the somatic rod to the end of the post oral arm), and the total length (TL) (length from the apical end of the larva to the end of the post oral arm) were measured (Fig. 1). Only larvae with normal morphology and vitality were considered on the basis of the descriptions of Fernández et al. (2019).

Data analysis: As a first step, a graphical exploration, based on the scatter and residual plots of the data, was performed in order to understand the relationship between the survival, response and the growth the variables (TL, $\mathrm{PO}$ and $\mathrm{SO}$ ), as well as to explain the explanatory variables (time -as DPF-, and density). To analyze the effect of density on survival, a Generalized Linear Model (GLM) was applied.
Different replicates were included in the model analysis in order to evaluate method error and in order to analyze whether the replicates presented similar values. Twelve different models, starting with a null model (simpler model without any explanatory variable) were proposed, and the complexity of the models resulted in a complex triple interaction model, between the explanatory variables referred to as DPF, replicates and density. To analyze growth over time after fertilization (DPF), a GLM was also applied. We proposed five models starting with a null model, whereby we increased complexity to result in a double interaction model taking place between the explanatory variables, DPF, and density. The best model was selected on the basis of the Akaike criterion, taking into account the residual analyzes, the explained variance (deviation) and the principle of parsimony or normality (Hurvich, Simonoff, \& Tsai, 1998). The Kruskal-Wallis non-parametric analysis of variance tests was used to determine the significance between densities. This was accompanied by peer reviews in order to identify the association between treatments.

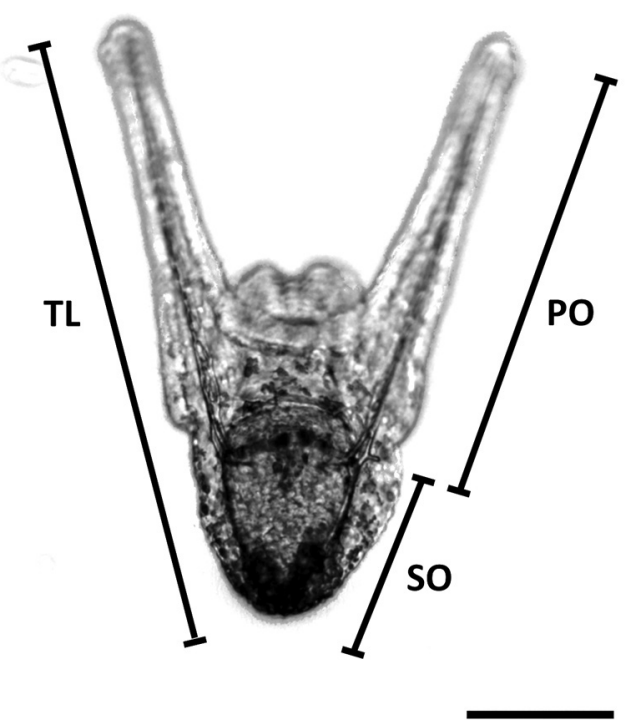

Fig. 1. Morphometric measurements to evaluate larval growth. $\mathrm{SO}=$ somatic rod. $\mathrm{PO}=$ post oral arm rod. $\mathrm{TL}=$ total larval length. Scale bar $=100 \mu \mathrm{m}$. 
All GLM analyzes were performed with the free software RStudio (version 3.5.1), and for the Kruskal-Wallis tests the software InfoStat was used. For all of the analyses, the level of significance applied was $\mathrm{P}$ value $<0.05$.

\section{RESULTS}

Survival: Larval survival (\%) decreased over time differently for each density treatment. The lowest values were for the lowest density ( 1 larva. $\left.\mathrm{ml}^{-1}\right)$, decreasing to $70 \%$ in the first sampled period (5 DPF), and decreasing to less than $20 \%$ by the end of the experiment (14 DPF). The intermediate density treatments recorded a survival percentage between $70 \%$ and $85 \%$ up to $11 \mathrm{DPF}$, and a notable decrease by $14 \mathrm{DPF}$ (3 larvae. $\left.\mathrm{ml}^{-1}\right)$. A high, and more stable, survival percentage of approximately $82 \%$ throughout the entire sample period was found in the 5 larvae. $\mathrm{ml}^{-1}$ treatment, which gradually decreased to be around $54 \%$ by 14 DPF. The higher density treatment (10 larvae. $\mathrm{ml}^{-1}$ ) showed high survival, exceeding $90 \%$, until $11 \mathrm{DPF}$, when it started to decrease to approximately $40 \%$ by 14 DPF (Fig. 2).

Table 1 shows the results of the GLM analysis for survival. The most complex model, which included the triple interaction between density, time (DPF) and replicates, appeared to be best matched with the data.
TABLE 1

Generalized Linear Model analysis for larval survival of Arbacia dufresnii. In bold, the model with the best fit according to the Akaike information criterion (AIC). $\mathrm{DPF}=$ days post fertilization.

\begin{tabular}{lcc}
\multicolumn{1}{c}{ Model for survival } & d.f. & Akaike \\
1. Null model & 1 & 247544.75 \\
2. Density & 4 & 88215.902 \\
3. DPF & 7 & 174118.85 \\
4. Replicates & 2 & 102241.47 \\
5. Density + DPF & 10 & 14790.003 \\
6. Density + replicates & 5 & 88212.401 \\
7. DPF + replicates & 8 & 28815.572 \\
8. Density * DPF & 28 & 7333.772 \\
9. Density * replicates & 8 & 87362.07 \\
10. DPF * replicates & 14 & 26581.575 \\
11. DPF + replicates + Density & 11 & 14025.098 \\
12. DPF * Replicates * Density & 56 & 3558.037 \\
\hline
\end{tabular}

\begin{abstract}
Abnormal larval development: During the experiment, morphologically normal larvae, and larvae with varying abnormal morphotypes were found (Fig. 3). The most common morphotype is represented in Fig. 3A. On the other hand, morphologically abnormal larvae can be larvae with very small post oral arms (Fig. 3B), larvae with a wide angle between post oral arms (Fig. 3C), larvae with crossed post oral arms (Fig. 3D), and larvae with square apical end (Fig. 3E). These abnormal morphotypes appeared on $8 \mathrm{DPF}$, registering
\end{abstract}

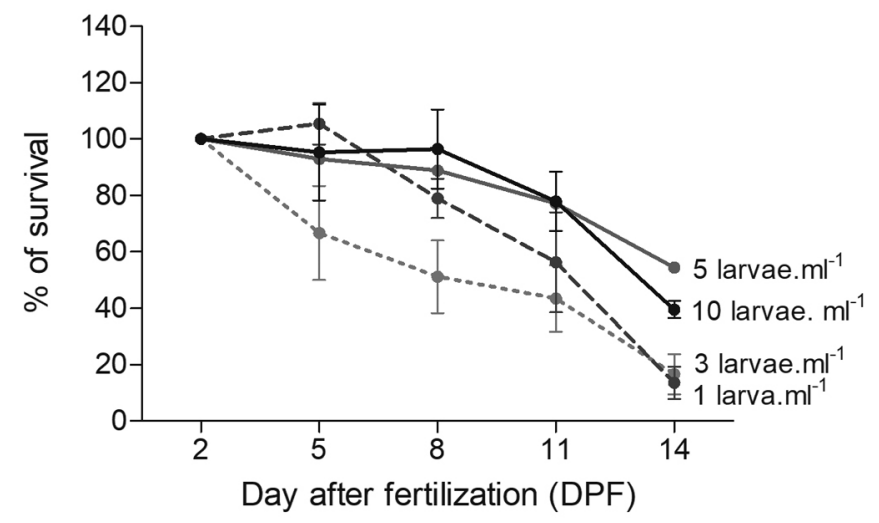

Fig. 2. Arbacia dufresnii larval survival percentage through time as regards four different densities: 1, 3, 5 and 10 larvae. $\mathrm{ml}^{-1}$ (mean \pm standard error). 
approximately $10 \%$ in all treatments. However, the percentage of abnormal larvae observed throughout the experiment varied with density, reaching more than $35 \%$ in the lowest density $\left(1\right.$ larva. $\mathrm{ml}^{-1}$ ) by day 14 , less than $20 \%$ in intermediate densities $\left(3\right.$ larvae. $\left.\mathrm{ml}^{-1}\right)$ and less than $10 \%$ in the highest density (5 and 10 larvae. $\mathrm{ml}^{-1}$ ) (Fig. 4).

Growth: Larvae size was similar in all densities at the initiation of the experiment.
With time (DPF), the PO and TL increased in all densities but showed differential growth, both in the length of PO (Fig. 5A) and in TL (Fig. 5B). The differences in larvae growth were more evident by the end of the experiment, when both PO and TL, showing the lowest density (1 larva. $\left.\mathrm{ml}^{-1}\right)$, were two-fold higher than in the higher density (5 and 10 larvae. $\left.\mathrm{ml}^{-1}\right)$, evidencing significant differences $(\mathrm{KW}=$ $22.49, \mathrm{P}=0.0001$, and $\mathrm{KW}=28.25, \mathrm{P}<0.0001$, respectively). There was no change in $\mathrm{SO}$ over
A

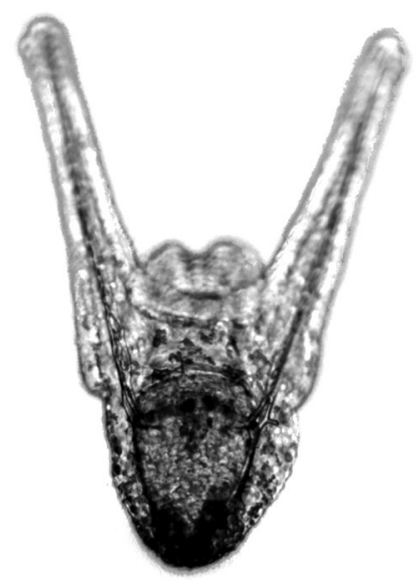

B
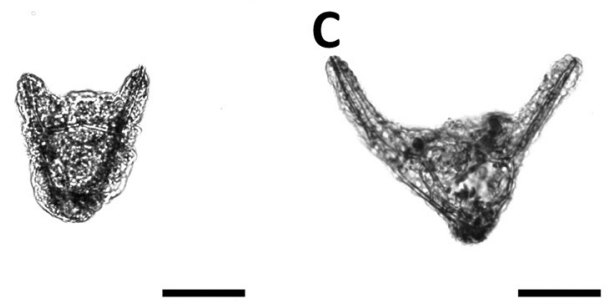

D

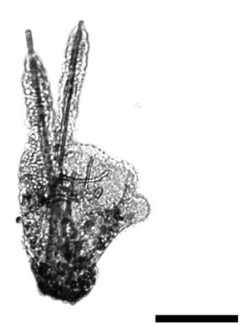

E

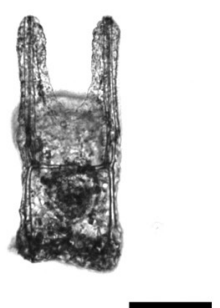

Fig. 3. Larval morphotypes of Arbacia dufresnii taken with Leica DM 2500 software (10X magnification).

A. Normal. B-E. The most representative abnormal larval morphotypes. Scale bar $=100 \mu \mathrm{m}$.

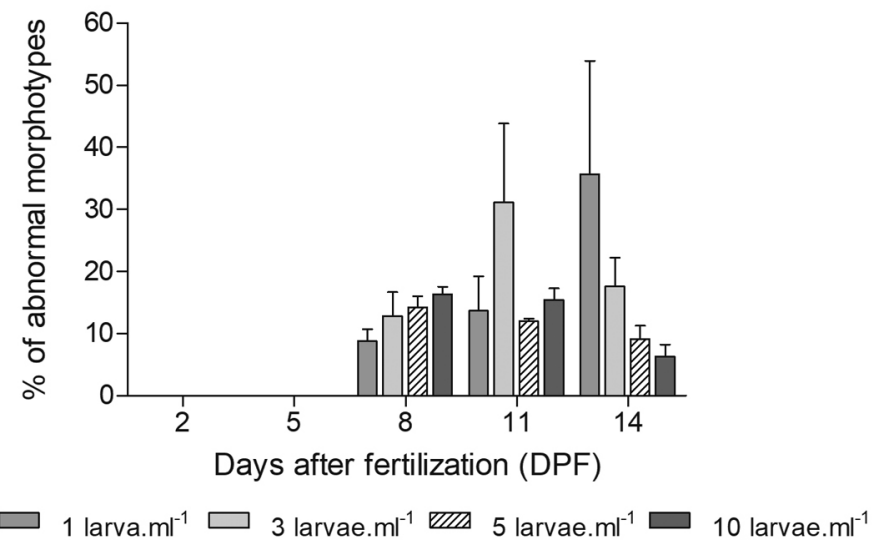

Fig. 4. Larvae with abnormal morphotypes (\%) during the experiment (mean \pm standard error).

On days 2 and 5 after fertilization, larvae did not present abnormal morphotypes. 

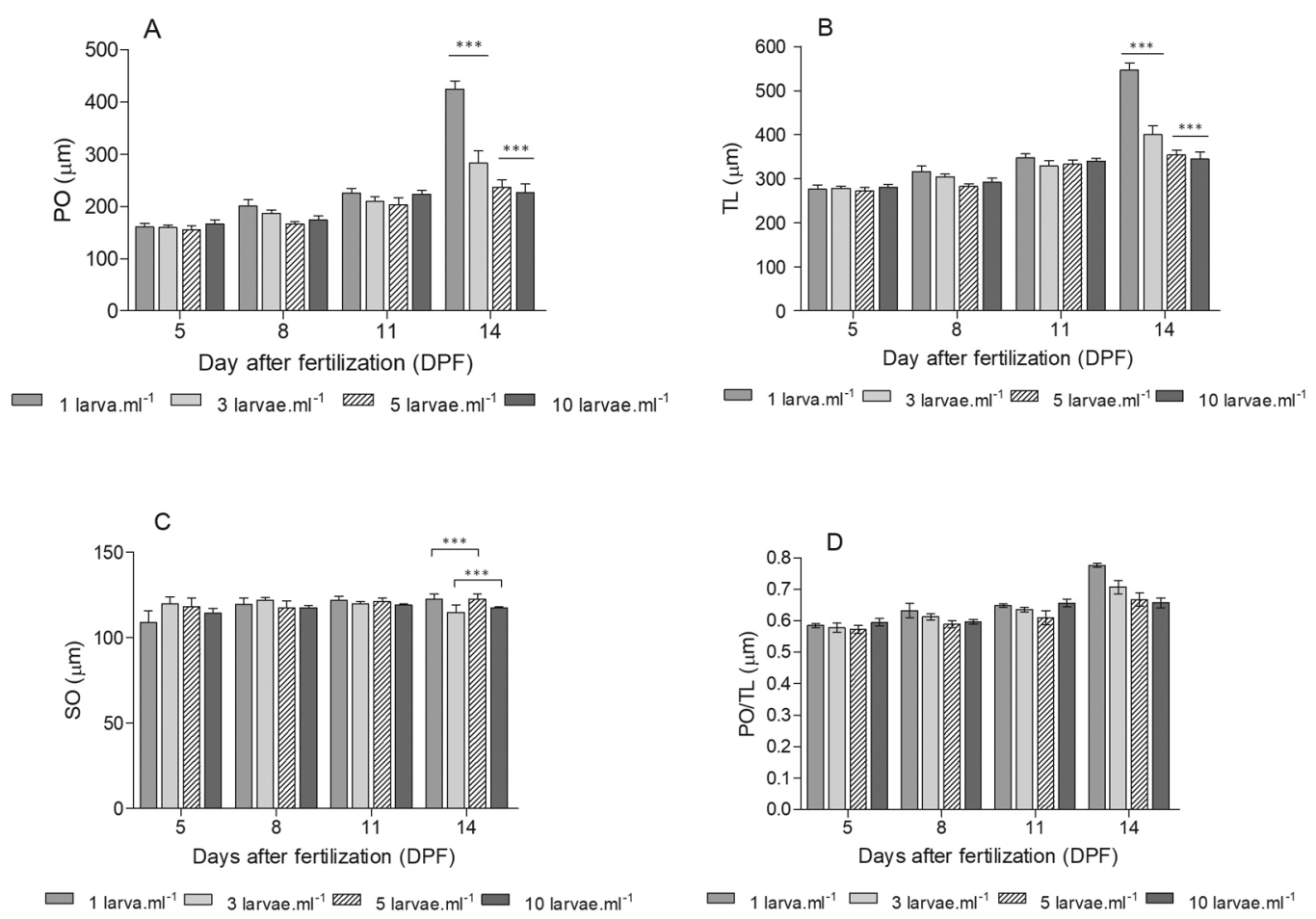

Fig. 5. Arbacia dufresnii larvae growth. A. Post oral arm rod larval length (PO). B. Total larval length (TL). C. Somatic rod larval length (SO). D. Morphometry index. (Mean between 3 and 5 measures \pm Standard error) (***and * denotes significant differences $\mathrm{P} \leq 0.001$ and $\mathrm{P}=0.0334$, respectively).

time; however, there were significant differences between densities at 8 and $14 \mathrm{DPF}(\mathrm{KW}=$ $8.66, \mathrm{P}=0.0334$, and $\mathrm{KW}=14.28, \mathrm{P}=0.0019$, respectively) (Fig. 5C). Throughout the sample period, there were slight variations in the morphometric index as regards the different larvae densities, and these differences become more evident by 14 DPF (Fig. 5D). These differences indicate that there is a relationship between the treatments studied and the degree of growth of the post oral arms.

Table 2 shows the results of the GLM analysis as regards growth. The most complex model, which includes the interaction between density and time (DPF), was the best fit for the data concerned.

\section{DISCUSSION}

The optimal culture density found for $A$. dufresnii larvae was higher than that usually observed for other species. In Evechinus chloroticus, Lytechinus variegatus, Paracentrotus lividus and Loxechinus albus it was suggested, to increase survival, to culture with densities of 1 larva. $\mathrm{ml}^{-1}, 0.25$ or 0.5 larvae. $\mathrm{ml}^{-1}, 0.06$ larvae. $\mathrm{ml}^{-1}$ and 0.7 larvae. $\mathrm{ml}^{-1}$, respectively (Buitrago \& Lodeiros-Seijo, 2005; Salas-Garza et al., 2005). However, for Arbacia stellata a similar density was proposed (4 larvae. $\mathrm{ml}^{-1}$ ) (Díaz-Martínez, 2019). Differences in larvae size among species may be related to the density found in cultures. Evechinus chloroticus two-armed pluteus larvae exceeds the 200 $\mu \mathrm{m}, L$. variegatus, two-armed pluteus larvae is around $400 \mu \mathrm{m}$, P. lividus four-armed pluteus larvae that exceeds $600 \mu \mathrm{m}$, and L. Albus reaches approximately $500 \mu \mathrm{m}$ (Fenaux et al., 1994; Lamare \& Baker, 1999; Buitrago \& Lodeiros-Seijo, 2005; Cárcamo et al., 2005). Arbacia dufresnii at the same stages of development, presents larvae of similar size than 
TABLE 2

Generalized Linear Model analysis for larval growth of Arbacia dufresnii. In bold, the model with the best fit according to the Akaike information criterion (AIC). DPF $=$ days post fertilization. $\mathrm{PO}=$ post oral larval length. $\mathrm{TL}$ $=$ total larval length. $\mathrm{SO}=$ somatic rod larval length.

\begin{tabular}{lcc}
\multicolumn{1}{c}{ Model for PO } & d.f. & Akaike \\
1. Null model & 1 & 8218.877 \\
2. Density & 4 & 7973.662 \\
3. DPF & 4 & 6594.189 \\
4. Density + DPF & 7 & 6152.789 \\
5. Density * DPF & 16 & $\mathbf{5 6 0 6 . 7 3 5}$ \\
Model for TL & d.f. & Akaike \\
1. Null model & 2 & 3882.068 \\
2. Density & 5 & 3874.307 \\
3. DPF & 5 & 3782.868 \\
4. Density + DPF & 8 & 3756.017 \\
5. Density * DPF & $\mathbf{1 7}$ & $\mathbf{3 6 9 6 . 8 4}$ \\
Model for SO & d.f. & Akaike \\
1. Null model & 1 & 2435.063 \\
2. Density & 4 & 2433.763 \\
3. DPF & 4 & 2437.452 \\
4. Density + DPF & 7 & 2435.777 \\
5. Density * DPF & 16 & 2439.823 \\
\hline
\end{tabular}

A. stellata (Díaz-Martínez, 2019). Size is an important factor in larvae culture, since at the same density the area occupied by each larva will be different according to the larvae's size. In this way, at high culture density, collisions between larvae can occur, increasing stress and affecting their development (Buitrago \& Lodeiros-Seijo, 2005). Therefore, it is probable that $A$. dufresnii can be culture at higher densities without affecting survival due to its small size.

Abnormal morphotypes decreased survival in $A$. dufresnii since these morphotypes do not prosper. At $8 \mathrm{DPF}, 10 \%$ of abnormal morphotypes were found in all densities. However, the extreme values of density ( 1 larva. $\mathrm{ml}^{-1}$ and 10 larvae. $\mathrm{ml}^{-1}$ ) showed at the end of the experience, the highest frequency in abnormal larval morphotypes and the lowest survival. The presence of these morphotypes in A. dufresnii larval culture was first described by Bernasconi (1942) and later on by Brogger (2005), who observed changes in morphology due to stress by increased temperature. In this way, the abnormal morphotypes may be related to an increase in the stress level in the extreme density cultures. The GLM analysis indicated that survival is affected by the interaction of three factors: time (DPF), density, and the replications within each treatment. The fact that the replicas were selected to be included in the model analysis indicates that the replicas are of utmost importance. Each culture replica significantly impacts the overall results in terms of larval survival, underlying the importance of the microenvironmental conditions (slight changes in temperature, light exposure, oxygen availability, etc.) in each culture and not only density as the main factor.

Morphometric measurements can reflect the most striking changes in organisms over time. In this study we focus on the space occupied by each larva in the culture and its effect and differential growth was observed between densities. Again, the extreme densities showed the greatest differences. In the lowest-density treatment both the PO and the TL of the larvae were higher than the rest of the treatments. On the contrary, in the highest-density treatment, both the PO and the TL were lower than the rest of the treatments. No differences were found in SO due to density, however SO is affected by variations in other variables such as $\mathrm{pH}$ in other species (Clark et al., 2009; García, Clemente, \& Hernández, 2018). The morphometric index is useful to analyze the percentage of larvae that occupy the post oral arms. As a result, this can provide information on the shortening or elongation of these arms at different densities and regardless of size. In this study, at low densities, the post oral arms are the longest structure in the larvae. However, at intermediate densities, the length of the post oral arms is not greater than the length of the SO, indicating a more proportional larva. The GLM analysis in all larval measurements showed that the best model was the one that considered the effect of the interaction between time (DPF) and density (treatments). The time component was expected, as the larvae develop with it and, in the process, grow and change their morphometry. 
Together, these results indicate that the higher the density of the culture, the smaller the size of the larvae.

It is important to note that food rations are also crucial, since inadequate food rations translate into development arrest (Astudillo et al., 2005), as well as changes in the size of the post oral arms (Hart \& Strathmann, 1994). Adequate density is crucial to avoid food competition and allow normal development to occur (Kalam-Azad et al., 2010), since overcrowding can drive competition (García et al., 2005; Kalam-Azad et al., 2010). However, in this study we provided food per larva, and not per unit of culture volume, in order to avoid food competition. This feeding regime eliminates food competition, but it modifies the availability of food as it changes the density of microalgae per unit culture volume (Unuma et al., 2015). This differentiation in the availability of food may produce a greater expenditure of capture effort, particularly in low density treatments. When availability of food is high, the post oral arms are short and energy is invested in accelerating development (Byrne et al., 2009). In contrast, when food is scarce, the post oral arms tend to lengthen to improve swimming and increase food capture (Fenaux et al., 1994; Hart \& Strathmann, 1994; Byrne, Sewell, \& Prowse, 2008; Adams et al., 2011). However, food availability is not the only cause of this effect. A nutritionally insufficient diet can also have the effect of lengthening the post oral arms (Cárcamo et al., 2005). We have shown that density is an important factor in A. dufresnii larvae culture, and seems to be species specific. We also found that the feeding regime used in this study may have influenced in a greater manner the larval growth and survival. This factor was especially visible at extreme densities, demonstrating the profound effects of food availability in larvae culture. Therefore, additional experiments will be necessary in order to differentiate the effect of culture density and the effect of food availability on larval development.

Combination of variables appear to explain survival and growth in the different treatments in A. dufresnii. On one hand, the lowest density treatment probably produces low food availability per unit of volume, evidenced by the larger size of the post oral arms developed by the larvae, and a high morphometric index. In addition, this stressor may explain the low survival rates found since the beginning in this treatment, and the increase in the occurrence of abnormal morphotypes along days. On the other hand, the higher density treatment probably produces overcrowding but not low food availability. This stressor may explain the smaller larvae size, and a low morphometric index, followed by a drop-in survival after 11 DPF. This decrease in survival is probably related to poor water quality, increased organic matter and metabolic waste substances due to the high density and food availability, as reported by other authors (Lamare \& Barker, 1999; Salas-Garza et al., 2005; Domínguez et al., 2007; Clark et al., 2009; Kalam-Azad et al., 2010). Culture water exchange was made every $48 \mathrm{~h}$. And even though culture water quality was evaluated with non-analytical methods, we cannot rule out that water quality affected the experiment, since larvae have a higher sensitivity (Lamare \& Barker, 1999; SalasGarza et al., 2005; Domínguez et al., 2007; Clark et al., 2009; Kalam-Azad et al., 2010). Since $A$. dufresnii has a relatively small larva, crowding only began to be notable at a high concentration (10 larvae. $\left.\mathrm{ml}^{-1}\right)$. To this species, intermediate density ( 5 larvae. $\mathrm{ml}^{-1}$ ) has shown to be optimal to balance the availability of food and overcrowding. This treatment also presents an intermediate larval size and a low level of abnormal morphotypes in the culture, increasing survival chances. However, since this experiment was not done until larvae were ready to settle, optimal density might change in more developed larvae.

This research represents the first study to analyze the larval culture density of $A$. dufresnii and its relevant information since this species has become the focus of a new aquaculture venture. 


\section{ACKNOWLEDGMENTS}

We are grateful to the diver Ricardo Bebo Vera for the collection of the sea urchins, to the Technician Mariano Moris for helping with the experiments and to Kathleen C. Anderson for the revision of English language. This work was undertaken with funds from PIP 0352/14, PICT 2018-1729. The sea urchins were collected by the Provincial Permit N`586/18.

\section{RESUMEN}

\section{Influencia de la densidad en la supervivencia y el desarrollo larvario del erizo de mar Arbacia dufresnii (Echinodermata: Echinoidea)}

Introducción: La densidad es uno de los factores críticos para las larvas de equinodermo para fines de acuicultura. Las larvas de Echinoplutei son muy sensibles al hacinamiento. Una alta densidad de cultivo puede provocar problemas con bacterias o protozoos, disminuyendo la supervivencia y generando morfotipos anormales. Objetivo: Evaluar el efecto de la densidad de cultivo sobre la supervivencia y el crecimiento larvario del erizo de mar Arbacia dufresnii. Métodos: Dos días después de la fertilización de $A$. dufresnii se mantuvieron los tratamientos a 1, 3, 5 y 10 larvas. $\mathrm{ml}^{-1}$, con tres repeticiones cada uno. Registramos la supervivencia y los morfotipos anormales periódicamente, así como el crecimiento: longitud de la varilla somática, longitud total y longitud de los brazos posorales. aplicamos modelos lineales generalizados. Resultados: La supervivencia depende de la densidad, el tiempo y las réplicas y sus interacciones. El crecimiento larvario dependió de la densidad y el tiempo, también de la interacción entre las variables. El tratamiento de 5 larvas. $\mathrm{ml}^{-1}$ tuvo la mayor supervivencia y condición larvaria. Conclusiones: El cultivo larvario de $A$. dufresnii tuvo los mejores resultados con 5 larvas. $\mathrm{ml}^{-1}$.

Palabras clave: Echinoplutei, crecimiento, morfometría, acuicultura, tratamientos.

\section{REFERENCES}

Adams, D.K., Sewell, M.A., Angerer, R.C., \& Angerer, L.M. (2011). Rapid adaptation to food availability by a dopamine-mediated morphogenetic response. Nature Communications, 2, 1-16.

Astudillo, D., Rosas, J., Velásquez, A., Cabrera, T., \& Maneiro, C. (2005). Crecimiento y supervivencia de larvas de Echinometra lucunter (Echinoidea: Echinometridae) alimentadas con las microalgas
Chaetoceros gracilis e Isochrysis galbana. Revista de Biología Tropical, 53(3), 337-344.

Bernasconi, I. (1942). Primeros estados larvales de Arbacia dufresnei (Blv). Physis: Revista de la Sociedad Argentina de Ciencias Naturales, 19(53), 305-317.

Bernasconi, I. (1966). Los equinoideos y asteroideos colectados por el buque oceanográfico R/V Vema, frente a las costas argentinas, uruguayas y sur de Chile. Revista del Museo Argentino de Ciencias Naturales Bernardino Rivadavia, 9(7), 147-175.

Brady, S.M., \& Scheibling, R.E. (2006). Changes in growth and reproduction of green sea urchins, Strongylocentrotus droebachiensis (Müller), during repopulation of the shallow subtidal zone after mass mortality. Journal of Experimental Marine Biology and Ecology, 335(2), 277-291.

Brogger, M.I. (2005). Biología reproductiva del erizo verde Arbacia dufresnii (Blainville, 1825) en costas del Golfo Nuevo, Patagonia (Bachelor thesis). Facultad de Ciencias Naturales y Exactas, Universidad de Buenos Aires, Argentina.

Brogger, M.I., \& Ivanov, V.A. (2010). Syndesmis patagonica n. sp. (Rhabdocoela: Umagillidae) from the sea urchin Arbacia dufresnii (Echinodermata: Echinoidea) in Patagonia, Argentina. Zootaxa, 2442, 60-68.

Brogger, M.I., Gil, D.G., Rubilar, T., Martinez, M.I., Díaz de Vivar, M.E., Escolar, M., ... Tablado, A. (2013). Echinoderms from Argentina: Biodiversity, distribution and current state of knowledge. In J.J. Alvarado \& F.A. Solís-Marín (Eds.), Echinoderm research and diversity in Latin America (pp. 359-402). Heidelberg, Berlin: Springer-Verlag.

Buitrago, E., \& Lodeiros-Seijo, C. (2005). Producción de larvas y postlarvas del erizo verdiblanco del Caribe Lytechinus variegatus (Echinodermata: Echinoidea) en condiciones de cultivo. Revista de Biología Tropical, 53(3), 319-328.

Byrne, M., Sewell, M.A., \& Prowse, T.A.A. (2008). Nutritional ecology of sea urchin larvae: Influence of endogenous and exogenous nutrition on echinopluteal growth and phenotypic plasticity in Tripneustes gratilla. Functional Ecology, 22, 643-648.

Byrne, M., Ho, M., Selvakumaraswamy, P., Nguyen, H.D., Dworjanyn, S.A., \& Davis, A.R. (2009). Temperature, but not $\mathrm{pH}$, compromises sea urchin fertilization and early development under near-future climate change scenarios. Proceedings of the Royal B: Society Biological Sciences, 276(1663), 1883-1888.

Cárcamo, P.F., Candia, A.I., \& Chaparro, O.R. (2005). Larval development and metamorphosis in the sea urchin Loxechinus albus (Echinodermata: Echinoidea): Effects of diet type and feeding frequency. Aquaculture, 249(1-4), 375-386. 
Castro, K. (2014). Dieta del erizo verde de mar Arbacia dufresnii y su relación con el alga invasora Undaria pinnatifida en costas del Golfo San José, Patagonia (Thesis). Universidad Nacional del Comahue, Argentina.

Catarino, A.I., De Ridder, C., Gonzalez, M., Gallardo, P., \& Dubois, P. (2012). Sea urchin Arbacia dufresnei (Blainville 1825) larvae response to ocean acidification. Polar Biology, 35, 455-461.

Clark, D., Lamare, M., \& Barker, M. (2009). Response of sea urchin pluteus larvae (Echinodermata: Echinoidea) to reduced seawater $\mathrm{pH}$ : A comparison among a tropical, temperate, and a polar species. Marine Biology, 156, 1125-1137.

Díaz-Martínez, J.P. (2019). Biología reproductiva, desarrollo larvario y efecto de la acidificación del océano en el éxito de la fertilización y desarrollo embrionario de Arbacia stellata (Blainville, 1825; Gmelin, 1788) (Echinodermata: Echinoidea) (Doctoral thesis). Universidad del Mar, México.

Díaz-Pérez, L., \& Carpizo-Ituarte, E. (2011). Effect of thermal stress on survival and delay of metamorphosis in larvae of the purple sea urchin Strongylocentrotus purpuratus. Ciencias Marinas, 37(4A), 403-414.

Domínguez, A., Rosas, J., Velásquez, A., Cabrera, T., \& Mata, E. (2007). Development, survival and growth of sea urchin Lytechinus variegatus (Lamarck, 1816) (Echinodermata: Echinoidea) fed on microalgae at two different salinities and temperatures. Revista de Biología Marina y Oceanografia, 42(1), 49-57.

Eckert, G.L. (1998). Larval development, growth and morphology of the sea urchin Diadema antillarum. Bulletin of Marine Science, 63(2), 443-451.

Epherra, L. (2016). Evaluación del impacto de invertebrados herbivoros nativos sobre el alga invasora Undaria pinnatifida: Arbacia dufresnii (Echinodermata: Echinoidea) como modelo de estudio (Doctoral thesis). Universidad Nacional de Mar del Plata, Argentina.

Epherra, L., Crespi-Abril, A., Meretta, P.E., Cledón, M., Morsan, E.M., \& Rubilar, T. (2015a). Morphological plasticity in the Aristotle's lantern of Arbacia dufresnii (Phymosomatoida: Arbaciidae) off the Patagonian coast. Revista de Biología Tropical, 63(2), 339-351.

Epherra, L., Gil, D., Rubilar, T., Perez-Gallo, A.S., Reartes, B., \& Tolosano, J.A. (2015b). Temporal and spatial differences in the reproductive biology of the sea urchin Arbacia dufresnii. Marine and Freshwater Research, 66, 329-342.

Epherra, L., Martelli, A., Morsan, E.M., \& Rubilar, T. (2017). Population parameters of the sea urchin Arbacia dufresnii (Blainville, 1825) from North Patagonian gulfs invaded by kelp Undaria pinnatifida
(Harvey) Suringar, 1873. Revista de Biología Tropical, 65(1), S101-S112.

Ettensohn, C., Wessel, G.M., \& Wray, G.A. (2004). The invertebrate deuterostomes: An introduction to their phylogeny, reproduction, development, and genomics. Methods in Cell Biology, 74, 1-13.

Ettensohn, C.A. (2017). Sea urchins as a model system for studying embryonic development. In M.J. Caplan (Ed.), Reference Module in Biomedical Sciences (pp. 1-7). Amsterdam: Elsevier.

Fenaux, L., Strathmann, M.F., \& Strathmann, R.R. (1994). Five tests of food-limited growth of larvae in coastal waters by comparisons of rates of development and form of echinoplutei. Limnology and Oceanography, 39(1), 84-98.

Fernández, J.P. (2019). Desarrollo neural en modelos embrionarios: el efecto de los factores tróficos (Doctoral thesis). Universidad Nacional de la Patagonia San Juan Bosco, Argentina.

Fernández, J.P., Epherra, L., Sepúlveda, L., \& Rubilar, T. (2019). Desarrollo embrionario y larval del erizo de mar verde Arbacia dufresnii (Echinodermata: Echinoidea). Naturalia Patagónica, 15, 44-58.

García, E., Clemente, S., \& Hernández, J.C. (2018). Effects of natural current $\mathrm{pH}$ variability on the sea urchin Paracentrotus lividus larvae development and settlement. Marine Environmental Research, 139, 11-18.

García, M., Rosas, J., Hernández, I., Velásquez, A., Cabrera, T., \& Maneiro, C. (2005). Supervivencia y crecimiento larval de Arbacia punctulata (Echinodermata: Echinoidea) alimentada con cinco microalgas a dos salinidades. Revista de Biología Tropical, 53(3), 329-336.

Hart, M.W., \& Strathmann, R.R. (1994). Functional consequences of phenotypic plasticity in echinoid larvae. Biological Bulletin, 186, 291-299.

Hinman, V.F., \& Burke, R.D. (2018). Embryonic neurogenesis in echinoderms. Wiley Interdisciplinary Reviews, Developmental Biology, 7, e316.

Hurvich, C.M., Simonoff, J.S., \& Tsai, C.L. (1998). Smoothing parameter selection in nonparametric regression using an improved Akaike information criterion. Journal of the Royal Statistical Society: Series B (Statistical Methodology), 60(2), 271-293.

Jimmy, R.A., Kelly, M.S., \& Beaumont, A.R. (2003). The effect of diet type and quantity on the development of common sea urchin larvae Echinus esculentus. Aquaculture, 220(1-4), 261-275.

Kalam-Azad, A., Mckinley, S., \& Pearce, C. M. (2010). Factors influencing the growth and survival of larval and juvenile echinoids. Reviews in Aquaculture, 2(3), 121-137. 
Kino, S. (2010). Reproduction and early life history of sea urchins, Arbacia dufresnei and Pseudechinus magellanicus, in Chiloé Island and Reloncaví Sound, Chile. Aquaculture Science, 58(1), 65-73.

Lamare, M.D., \& Barker, M.F. (1999). In situ estimates of larval development and mortality in the New Zealand sea urchin Evechinus chloroticus (Echinodermata: Echinoidea). Marine Ecology Progress Series, 180, 197-211.

Larraín, A., Mutschke, E., Riveros, A., \& Solar, E. (1999). Preliminary report on Echinoidea and Asteroidea (Echinodermata) of the Joint Chilean-German-Italian Magellan "Victor Hensen" Campaign, 17 October-25 November 1994. Scientia Marina, 63(1), 433-438.

McClay, D.R. (2011). Evolutionary crossroads in developmental biology: sea urchins. Development, 138, 2639-2648.

Newcombe, E.M., Cárdenas, C.A., \& Geange, S.W. (2012). Green sea urchins structure invertebrate and macroalgal communities in the Magellan Strait, southern Chile. Aquatic Biology, 15, 13-144.

Parra, M., Rubilar, T., Latorre, M., Epherra, L., Gil, D.G., \& Díaz de Vivar, M.E. (2015). Nutrient allocation in the gonads of the sea urchin Arbacia dufresnii in different stages of gonadal development. Invertebrate Reproduction \& Development, 59, 26-36.

Pechenik, J.A. (1999). Sobre las ventajas y desventajas de los estadios larvales en los ciclos de vida de los invertebrados marinos bentónicos. Serie del Progreso de la Ecología Marina, 177, 269-297.

Penchaszadeh, P.E., \& Lawrence, J. (1999). Arbacia dufresnei (Echinodermata: Echinoidea): a carnivore in Argentinian waters. In M.D. Candia-Carnevali \& F. Bonasoro (Eds.), Echinoderm Research (pp. 525530). Rotterdam: A.A. Balkema.

Rahman, S., Tsuchiya, M., \& Uehara, T. (2009). Effects of temperature on hatching rate, embryonic development and early larval survival of the edible sea urchin, Tripneustes gratilla. Biologia (Section Zoology), 64, 768-775.

Rosas, J., Velásquez, A., Fernández, S., Mata, E., \& Cabrera, T. (2009). Larval development and survival to metamorphosis of sea urchin Tripneutes ventricosus (Lamarck) (Echinodermata: Echinoidea) fed on microalgae at two temperatures. Revista de Biología Marina y Oceanografia, 44(2), 387-396.

Rubilar, T., \& Crespi-Abril, A. (2017). Does Echinoderm research deserve an ethical consideration?. Revista de Biología Tropical, 65(1), 11-22.
Rubilar, T., Epherra, L., Deias-Spreng, J., Díaz De Vivar, M.E., Avaro, M., Lawrence, A.L., \& Lawrence, J.M (2016). Ingestion, absorption and assimilation efficiencies, and production in the sea urchin Arbacia dufresnii fed a formulated feed. Journal of Shellfish Research, 35(4), 1083-1093.

Salas-Garza, A., Carpizo-Ituarte, E., Parés-Sierra, G., Martínez-López, R., \& Quintana-Rodríguez, R. (2005). Producción de juveniles de erizo rojo Strongylocentrotus franciscanus (Echinodermata: Echinoidea) en Baja California, México. Revista de Biología Tropical, 53(3), 345-355.

Stotz, W.B. (2014). Cultivo y producción masiva de juveniles de erizo rojo chileno Loxechinus albus (Molina, 1782) en laboratorio. Investigaciones Pesqueras, 38, 37-54.

Strathmann, R. (1987). Echinoderm larval ecology viewed from the egg. Echinoderm Studies, 2, 55-136.

Strathmann, R.R. (2014). Culturing larvae of marine invertebrates. In D.J. Carroll \& S.A. Stricker (Eds.), Developmental biology of the sea urchin and other marine invertebrates (pp. 1-25). New York: Humana Press.

Teso, S.V., Bigatti, G., Casas, G.N., Piriz, M.L., \& Penchaszadeh, P.E. (2009). Do native grazers from Patagonia, Argentina, consume the invasive kelp Undaria pinnatifida?. Revista del Museo Argentino de Ciencias Naturales Bernardino Rivadavia, 11(1), 7-14.

Unuma, T., Sakai, Y., Agatsuma, Y., \& Kayaba, T. (2015). Sea urchin aquaculture in Japan. In N.P. Brown \& S.D. Eddy (Eds.), Echinoderm Aquaculture (pp. 77-126). New Jersey: John Wiley \& Sons, Inc.

Vásquez, J., Castilla, J.C., \& Santelices, B. (1984). Distributional patterns and diets of four species of sea urchins in giant kelp forest (Macrocystis pyrifera) of Puerto Toro, Navarino Islands, Chile. Marine Ecology, Progress Series, 19, 55-63.

Williams, D.H.C., \& Anderson, D.T. (1975). The reproductive system, embryonic development, larval development and metamorphosis of the sea urchin Heliocidaris erythrogramma (Val.) (Echinoidea: Echinometridae). Australian Journal of Zoology, 23(3), 371-403.

Zaixso, H.E., \& Lizarralde, Z.I. (2000). Distribución de equinodermos en el golfo San José y sur del golfo San Matías (Chubut, Argentina). Revista de Biología Marina y Oceanografia, 35(2), 127-145.

Zárate, E., Díaz de Vivar, M.E., Ávaro, M.G., Epherra, L., \& Sewell, M. (2016). Sex and reproductive cycle affect lipid and fatty acid profiles of gonads of Arbacia dufresnii (Echinodermata: Echinoidea). Marine Ecology Progress Series, 551, 185-199. 